\title{
For An Ecological Awareness of Responsible Living
}

\section{Vereno Brugiatelli}

$\mathrm{PhD}$

\section{Abstract}

The entrenched and firm conviction that man is master of nature while being separate from it has fostered the culture of the indiscriminate use of natural resources, the destruction of eco-systems and a waste society. Over recent decades, behind the urgent need to halt the ecological drift, the natural landscape has been of considerable interest in various disciplinary contexts including biology, from which it has gained renewed consideration from the "ecology of landscape" perspective, and ethics. Once the theoretical aspects of the ecology of the landscape concept have been clarified, I will demonstrate that the human condition is part of the natural environment. On this basis I will highlight the necessity for man to develop an ecological awareness founded on responsibility regarding biodiversity. The ethics of responsibility, enlightened by an ecological awareness, have to inspire living and guide environmental policy-making.

Keywords: natural landscape, biodiversity, ecological awareness, living

\section{Introduction}

In the context of the ecology of the landscape, ecologists play a pivotal role in dealing with the problems related to the natural environment. Since the end of the $20^{\text {th }}$ century, new concepts of natural landscape and ecology of the landscape have been elaborated with the intention of gaining greater knowledge of the biological system. In spheres in which the landscape cannot be considered only from an aesthetic or geographic viewpoint, the role of the ecologist is considered indispensable in practical contexts such as: the elimination or reduction of harmful emissions, land and environmental planning, ecological network design, urban parks realization, and redevelopment of industrial areas etc. The landscape is an ecological system with its own typical features, but it also shares characteristics with other biological levels which are integrated through intricate recursive processes. In this respect the natural landscape system can be considered as self-regulating. It is a complex living system which includes man. 
Through biological and cultural interactions with the landscape, man both modifies and is, in turn, modified by the natural landscape. Man is part of the environment and the landscape. From this perspective, living is deeply rooted in this "co-belonging" situation. An integrated-biological consideration of the landscape is acquired with a mature ecological awareness fostered by a sense of responsibility, directed at the realization of an ethical life "with and for the landscape". Being "with" the landscape is an expression of man's integration with the landscape on a biological and ecological level, while being "for" the landscape regards man's commitment towards it from an ethical point of view. Such commitment relates the responsibility and awareness that the same biosphere is shared by all living creatures (Morin, 1999).

Gilles Clément, biologist and landscape architect, calls the space of biodiversity "Third Landscape". From an ethical perspective "The reality of the Third Landscape is of mental order (....) It is positioned in the ethical field of the permanent planetary citizen" (Clément, 2004, pp. 27-28). Biodiversity conditions not only our biological life, but also our ethical and cultural living by influencing our psychological, physical, and social well-being. Thus, as stated by Edgar Morin (2015), there is great need for ecological awareness, intended as the awareness of living with all mortal beings in the same living space (the biosphere).

\section{Biodiversity and ecological awareness}

It is not only man that "makes" the landscape, but also all the other systems. Without doubt, the human species is the system that contributes most to shaping it through our technological and cultural apparatus, but all living creatures play a part in its transformations: biodiversity has always produced variety and richness of the landscape. Global environmental destruction can be dealt with only by being careful not to destroy the diversity of living creatures. Unfortunately, every year thousands of species disappear due to man's impact. In order to conserve the natural landscape specific government intervention often produces contradictory results.

According to Clément, rather than artificial intervention, nature needs to be left to take its natural course in its own time. He states that the territory and the environment already constitute the landscape even without man's intervention, even on a cultural level. It is the abundance of life, towards which man must direct his sense of responsibility and attention, that provides the conditions for human living. Human existence, health and well-being depend on this. The city-countryside and city-land relationships can therefore be considered in the light of such landscape. The so-called natural landscapes are the consequence of the diversity of life. Diversity "refers to the number of living species including animals, plants and simple organisms (bacteria, virus etc.) with the human element constituting a single species whose diversity is apparent through ethnic and cultural variations" (Clément, 2004, p. 10).

The third landscape is the territory of living diversity, representing a refuge. Vast areas of land, which appear unexploited by man have, in fact, been modified. These 
include rivers that have undergone deviations or narrowing, a large artificial lake, managed woods and forests, hilly green spaces dedicated to livestock etc. Man's presence involves the reduction in the diversity of living things. On the one hand, it contributes to the creation of cultural landscapes, while, on the other, it often impoverishes the landscapes formed by biodiversity over long periods of time. Agriculture and livestock farming are activities which reduce diversity and erode the Third landscape. "The Third landscape, land of diversity, is directly linked to demographics, a taboo subject." (Clément, 2004, p. 26).

The diversity of life, given by the number of species and variety of behaviours, is connected to the existence of the Third landscape. The number of species and variety of behaviours depend on environmental changes. Human activity leads to rapid and significant modifications of the environment which greatly impact the number of species and behaviours. By compromising the Third landscape, since man is drastically limiting the "possibility of biological invention", diversity and the range of behaviours is reduced thus jeopardising man's life on earth.

\section{Ecological awareness, responsibility and global landscape}

Clément appears to be pessimistic about the role of the institutions regarding the landscape even when it is elevated to the ranks of national or world heritage. In this case the Third landscape is put under surveillance, accepted as a model and organised in such a way as not to undergo changes over time. But Clément observes that with such measures the Third landscape is destined to die (Clément, 2004, pp. 55-56). Paradoxically, it is the disinterest on the part of the institutions to ensure the "conservation and retention of diversity" (Clément, 2004, p. 56).

The institutions become disinterested in the Third landscape because its exploitation is impossible and unprofitable since the space is inconvenient, impractical, discarded, on the margins, uncertain, unwanted and without hope. Market dynamics consider only the profit and accumulation of material wealth to be gained from the landscape; the unexploitable parts of the Third landscape are saved as they are considered useless. It is precisely what is economically unprofitable that is considered useful for the living world. Knowing how to live the landscape signifies seizing the useful from the useless. Conserving biodiversity is possible if, finally, it is considered as uselessness. From uselessness may spring total usefulness for man. Therefore, value needs to be bestowed upon a certain form of unproductivity and land management policies need to be viewed with concern.

Responsibility towards the Third landscape is possible by cultivating the a-logic of uselessness, considering it as a material advantage and not as a tourist attraction. In short, it should not be seen as an economic resource but, rather as a source of life. So, responsibility is key and must be accepted regarding the fragility of the life-cycle systems. This means being responsible for the actions which may trigger long-term consequences in the equilibrium of living systems upon which we depend. In an era 
of "technological advancement", in Das Prinzip Verantwortung (1979), Hans Jonas highlights the inadequacy of traditional ethics regarding the problems raised by the "modified nature of man's actions". In ancient times, man's actions produced consequences in the limited sphere of human interaction without affecting nature from which man, at times, needed to defend himself. (Jonas, 1979, pp. 23-26). For such human activity, actions of "simultaneity and proximity" were sufficient, while for homo faber the situation changed completely. Technology enables our actions to have effects both over long distances and well into the future. For this reason, an "ethics of the future" is needed in the name of responsibility for future generations. A suitable imperative for the new type of human activity, aimed at the new type of actor would be: "Act so that the consequences of your actions are compatible with the continuity of authentic human existence on earth" (Jonas 1979, p. 36).

Jonas' imperative defends the biosphere by recognising the value and dignity of nature and regards mankind by recognising man as an "end in itself" with an intrinsic value. Jonas favours an extension of rights also to nature and the stipulation of a contract in harmony and reciprocity with nature (Jonas, 2000, p. 4). The natural landscape is pre-cultural, in which we are deeply rooted and to which we belong. This means that we are connected on a psychic-organic level with the landscape understood as bios as it is part of both our organic and subconscious life (Brugiatelli, 2020, pp. 101-103).

\section{The overall enhancement of the landscape}

The wealth and variety of such syntheses depend on the richness and variety of life. Ethos, in terms of ecologically aware living, translates into actions respectful of the richness and variety of living things and their behaviours without accelerating chaos (entropy) in nature (Venturi Ferriolo, 2002). Our actions must respect the natural landscape and be aimed at re-use rather than waste by supporting the circularity of natural processes at the expense of the destructive linearity of the market-oriented production processes. The landscape is enhanced if accompanied by responsible transformations for future generations. From this viewpoint responsible enhancement involves improving the quality of living in close relation to the quality of the environment. But what do we mean by "enhancement of the landscape"? There is no unequivocal answer, if anything, it is provided by a set of different enhancements.

The aesthetic enhancement of the landscape, beyond its romantic and idealistic acceptance, originates from the enhancement of the environment and living. Enhancing the environment means adopting codes of behaviour together with respectful and pondered techniques regarding the management of resources, the transformation of raw materials, the production and transportation of goods, waste disposal and biodiversity. The enhancement of living means urbanisation and construction in a way which guarantees the safety of the inhabitants in the case of 
catastrophic events caused by atmospheric phenomena or events relating to the geomorphology of the land and sub-soil. In addition, it means building in order to create places which promote human interaction and numerous possibilities to interact with the environment through activities like gardening, cultivation, walking for pleasure and sports. It also implies a diet composed of certified organic food etc. The overall enhancement of the landscape thus requires the enhancement of a whole series of components of the territory, the environment, the history and the culture.

\section{Conclusive considerations}

We believe it is time to achieve an alliance and interaction between the cultural landscape, which is the result of human behaviour and the "anthropization" of the land, and the natural landscape as an outcome of the diversity of living things and their behaviours. Modern man has strikingly accelerated biological time leading to a significant increase in entropy with the consequent disappearance of numerous species. The Third landscape changes form and dimension through the "market game and political game". This strong pressure involves a regression of diversity while weak pressure facilitates "balanced diversity that can positively influence the general environment" (Clément, 2004, p. 36) and, consequently, fosters man's psychicphysical well-being. Thus, the Third landscape commits man-citizen from an ethical and political point of view.

A democratic philosophy of the Third landscape is needed to foster the formation of a collective awareness. Consciousness on an individual level results from a process of the gaining of awareness of our "co-belonging" to the biodiversity of the landscape. Such awareness can be fostered by a non-instrumental attitude, by an understanding of nature. Without doubt, such an approach may enhance awareness that we humans play an interactive role in a network of exchange and interrelationships being part of a complex system (complexus). As Edgar Morin explains, complex means a system in which all the parts are interconnected. The task of collective awareness, fostered by the ethics of responsibility, is to delineate and realize a project which involves the democratic and political community. It is important not to confuse or to separate ethics from politics. A "debated reciprocity" is necessary to avoid conflict which can be overcome when politics allows itself to be guided by the ethics of responsibility. When motivated by an ethical code, politics serves the whole community rather than only benefiting a few.

Today we still observe profound immaturity and, in that sense, lack of acknowledgement-awareness regarding the human condition. Mankind requires a programme of individual and collective, and ethical and political awareness with regard to its belonging to the Landscape-World. As stated by Edgar Morin as living beings on this planet, "nous dépendons vitalement de la biosphère terrestre ; nous devons reconnaître notre très physique et très biologique identité terrienne" (Morin, 1999, p. 25). 
Considering the landscape as a cultural product must therefore be integrated into the pre-existing biological landscape. The global landscape is a bio-cultural landscape for us to acknowledge as part of the process of gaining ecological awareness, defined by Morin as the awareness of living with all mortal beings in the same living sphere (biosphere). "Recognising our consubstantial link with the biosphere leads us to the abandonment of the Promethean dream of the dominion of the universe to foster, to the contrary, the aspiration of conviviality on Earth" (Morin, 1999, p. 41). At this stage, we urgently need an education based on the ethics of global awareness linked to ethical and political responsibility towards biodiversity.

\section{References}

[1] Berleant, A. (1997). Living in the Landscape. Toward an Aesthetics of Environment, Lawrence 1997, pp. 9-24.

[2] Brugiatelli, V. (2020). Ermeneutica del paesaggio. Esistenza, interpretazione, racconto. Trento: Tangram.

[3] Brugiatelli, V. (2017). Living, narrating and enhancing the landscape through the ethics of responsibility. Amsterdam: International Conference on Social Sciences, EUSER, vol. II, pp. 61-64.

[4] Carlson, C. (2002). Aesthetics and the Environment. The Appreciations of Nature, Art and Architecture. London-New York: Routledge.

[5] Clément, G. (2004). Manifeste du Tiers paysage. Paris: Sujet/Objet.

[6] Clément, G. (1991). Le jardin en mouvement. Paris: Pandora.

[7] D'Angelo, P. (2019). Filosofia del paesaggio. Macerata: Quodlibet.

[8] Jonas, H. (1979). Das Prinzip Verantwortung. Frankfurt - am Main: Insel Verlag.

[9] Jonas, H. (2000). Sulla sofferenza, «Ragione pratica», VII, 15, pp. 33-52.

[10] Jullien, F. (2014). Vivre de paysage ou L'impensé de la raison. Paris: Gallimard.

[11] Morin, E. (1999). Les sept savoirs necessaries à l'éducation du futur. Paris: Organisation des Nations Unies pour l'éducation, la science et la culture.

[12] Morin, E. (2015). Penser global. L'homme et son univers. Paris: Èditions Robert Laffont, S.A.

[13] Venturi Ferriolo, M. (2002). Etiche del paesaggio. Il progetto del mondo umano. Roma: Editori Riuniti. 